Editor's Note: Norit Carolina Libraries presents this feature in recognition of the increase in excellent unsolicited manuscripts that merit publication, but are not necessarily related to each issue's specific theme.

\title{
Leisure Reading Collections in Academic Libraries: A Survey
}

\author{
by Linda A. Morrissett
}

$M$

any articles exist in the professional literature about encouraging students to read books that interest them, from kindergarten through high school and in summer reading programs. There is even a respectable amount of material concerning adult readers as targeted reading audiences. Reading habits of college students, however, are infrequently addressed.

Academic librarians are concerned primarily with the information needs of our students and faculty, which are, of course, centered around the curriculum. We also assume that our students have healthy reading interests and habits, long instilled in them by the aforementioned K-12 reading programs. Many academic libraries affirm these reading interests by providing leisure or browsing collections of popular materials for their patrons' pleasure and convenience.

\section{A Leisure Collection Experience}

In the summer of 1987, Western Kentucky University Libraries initiated a small collection targeting the recreational reading needs of the university community. The primary reason behind this project was to encourage students to develop regular reading habits which they might continue beyond their formal education experlence.

A separate leisure collection makes it easy for patrons who come to the library just to find a book to read. Attractive displays of popular books entice students to grab one to read as they pass time in the library between classes or to check one out on impulse. Popular reading material is available to Western students at the campus bookstore, area bookstores, and the Bowling Green Public Library, but these sources require more effort, time, and money than many students can spare. Although the local public library is located within walking distance of campus, and many Western students are eligible to obtain borrowing privileges, its collection and services are strained to serve the growing needs of local residents.

Western's Leisure Reading collection began with a core of 220 books obtained through Brodart's McNaughton hardback subscription plan. Bestsellers and other popular books not normally acquired for the regular collection are selected by a committee of librarians and paraprofessionals. Orders are placed monthly using an annotated checklist of titles supplied by the vendor, and the books arrive pre-processed. In-print books which are recommended by students and staff but do not appear on the vendor's list also are ordered on the leasing plan. The most staff time involved with the collection is spent adding and deleting brief cataloging records in the database and in a quarterly weeding project. Library staff enjoy the diversion of working with these popular books, and they often take advantage of being first to check them out.

The Leisure Reading collection is shelved in an alcove near the circulation desk and main library entrance. Comfortable upholstered chairs are arranged in this alcove, with a few of the leisure books scattered on end tables to catch potential readers' interest. A title list of books in the collection also is left on a table for those who wish to scan it.

Most titles selected from the subscription plan are fiction. Popular best-selling authors such as Danielle Steel, Dominick Dunne, Tom Clancy, and John Grisham, and mystery writers such as Sue Grafton, Dick Francis, and Lilian Jackson Braun are the most heavily represented. Contemporary mainstream fiction is always available: works by John Barth, Alice Walker, Walker Percy, Toni Morrison, Joyce Carol Oates, Chaim Potok, James Dickey, and Margaret Atwood are often selected. Biographies of political figures (Kennedys, Clintons, Reagan, Carter, Truman), other significant personalities (Thurgood Marshall, Leonard Bernstein, Norman Schwarzkopf, Rush Limbaugh, Arthur Ashe), and the British royal family are popular selections. The humor of authors such as Dave Barry, Lewis Grizzard, and Andy Rooney is available, as are science fiction (Ben Bova, Arthur Clarke) and fantasy (Anne McCaffrey, Piers Anthony). Books about health, education, business, the environment and other contemporary issues are included as well.

Reaction to the Leisure Reading collection has been quite positive among students, staff, and faculty, and circulation has steadily grown. The size of the collection was increased to three hundred titles in 1989, and to five hundred titles in 1992. A popular magazine collection was initiated in the fall of 1992 to further encourage recreational reading. Current issues of about fifteen popular titles, such as Car and Driver, Music City News, Vanity Fair, Sports Afield, Advocate, Down Beat, Details, Countrv Living and McCalls are displayed in a study lounge area where food and beverages are permitted. As with the leisure books 
collection, patrons' recommendations for additions to the collection are encouraged and usually incorporated.

The success of this thriving Leisure Reading collection leads to several questions. What is the nature and source of leisure reading collections in academic libraries and how widespread are they? How are they treated bibliographically? Are they more likely to be found in smaller colleges than large universities? The best way to answer these questions is to survey academic libraries. This paper provides the results of a survey of academic libraries in southeastern states conducted by the author in 1993.

\section{Survey Methodology}

A brief survey instrument (Appendix A) was designed to find out about leisure or browsing collections of books, magazines, and videos in academic libraries. It sought information about the size and nature of the collections, their bibliographic access, their overall use, and the popularity of subjects. Finally, it requested the size of the student body and whether the school is private or publicly-supported.

The survey was sent to 120 academic libraries in twelve southeastern states (Virginia, West Virginia, North Carolina, South Carolina, Georgia, Florida, Alabama, Mississippi, Tennessee, Kentucky, Arkansas and Louisiana) during October 1993. These libraries serve student bodies ranging from 600 to 28,000 , but the majority are in the 2,000 to 8,000 student range. Both private and state-supported colleges and universities were included in the survey.

Results were tallied to determine the prevalence of leisure or browsing collections and to attempt to draw a general profile of such collections. Librarians' comments were recorded separately with the intent to supplement the statistical data given.

\section{Response}

Eighty-five of the 120 academic libraries surveyed returned the survey, a return rate of about 75 percent. Thirty-eight ( 45 percent) of the libraries surveyed indicated they do have a browsing or leisure reading collection. Forty-seven of the 85 academic libraries ( 55 percent) responding to the survey indicated they have no leisure collection, or at least none specifically designated as such.

\section{Leisure Collections}

Several of the libraries surveyed have more than one type of material in their leisure collection. Any combination of book rentals, paperback books, hardback books, gift books, videos, and magazines may be maintained; each "mini-collection" may be cataloged and circulated differently. The 38 libraries described a total of 61 such collections they maintain. (This explains the apparent discrepancy in the data tabulated below).

Most of these 61 collections are books, but a few also include magazines (7 libraries) and videos (9 libraries). Sixteen libraries participate in a rental plan from either Baker \& Taylor or McNaughton. Other collections include donations from staff and Friends organizations, or even items selected from the regular collection. Fifteen libraries maintain paperback leisure collections.

The size of institution does not appear to be a factor in whether the library has a leisure collection. (See Table I) In each size-range category, a fairly even distribution can be seen. The top and bottom range, over 20,000 and under 1,000 enrollment respectively, are more likely not to have leisure collections. However, the sample size is not large enough to assume a correlation.

Private schools are somewhat more likely to have leisure collections: 44 percent of private colleges responding to the
The following tables show responses from the 38 libraries which have leisure collections. Percentages shown are of all positive respondents, not the total sample. (Note: The total will not be 38 in these tables since several libraries have more than one type of leisure collection, and there was an occasional "no response".)

1. Responses by Size of Institution

\begin{tabular}{|c|c|c|}
\hline $\begin{array}{l}\text { Number of } \\
\text { Students }\end{array}$ & $\begin{array}{c}\text { Leisure/Browsing } \\
\text { Collection }\end{array}$ & $\begin{array}{l}\text { No Leisure } \\
\text { Collection }\end{array}$ \\
\hline $600-1,000$ & 2 & 4 \\
\hline $1,001-3,000$ & 11 & 9 \\
\hline $3,001-6,000$ & 9 & 10 \\
\hline $6,001-10,000$ & 4 & 5 \\
\hline $10,001-15,000$ & 5 & 5 \\
\hline $15,001-20,000$ & 2 & 2 \\
\hline 20,001 & 3 & 5 \\
\hline Size not given & 2 & 3 \\
\hline
\end{tabular}

II. Private vs. Publicly Supported Institutions

\begin{tabular}{|c|c|c|}
\hline & $\begin{array}{c}\text { Leisure } \\
\text { Collection } \\
\end{array}$ & $\begin{array}{l}\text { No Leisure } \\
\text { Collection }\end{array}$ \\
\hline Private & 12 & 15 \\
\hline Public & 19 & 30 \\
\hline
\end{tabular}

III. Types of Collections

Leased books

$16(42 \%)$

Baker \& Taylor

$(11 \%)$

McNaughton

$(29 \%)$

Library's books

$(37 \%)$

Paperbacks

$(40 \%)$

Magazines

Videos

$9(24 \%)$

IV. Bibliographic Access

Full bibliographic record

21 (55\%)

Brief bibliographic record

$13(34 \%)$

Separate list or file only

$5 \quad(13 \%)$

No bibliographic access

$7 \quad(18 \%)$

V. Circulation Procedures

Circ records integrated with

"regular" collection automated circ system manual circ system

$30 \quad(79 \%)$

22 (58\%)

8 (21\%)

Circ records kept separately

No circ records kept

Length of Loan as Compared to "regular" collection
Same
$21 \quad(55 \%)$
Shorter
$11(29 \%)$

\section{Most Popular Genres}

Mystery

22

Historical Romance

Fiction

$12(32 \%)$

Science Fiction

$(29 \%)$

Biography

(26\%)

Horror

9 (24\%)

$4 \quad(11 \%)$ 
survey have leisure collections, compared with 39 percent of the state-supported institutions which report having such collections. (Table II)

\section{Bibliographic Access}

Overall, patrons have good bibliographic access to leisure collections. Twenty-one collections described by survey respondents are fully cataloged, while 13 have brief records in their catalog. Five collections have only a separate file or list for patron access: 3 rental collections, 1 video collection. Three collections are accessible by a separate list in addition to the catalog.

Seven collections have no bibliographic access; 6 of these are paperback browsing collections kept in display areas for patrons to take and read at will. One uncataloged collection is from a rental plan.

Bibliographic control is a significant investment in the collection, and the strong showing of bibliographic access to leisure materials indicates an acknowledgement of the importance of the collections. Paperbacks have a short shelf-life, and are understandably less likely to be cataloged.

\section{Circulation}

Thirty-two of the 38 respondents said they use the same circulation system for leisure materials as for the regular collection. Twenty-one of these libraries use the same loan period as for similar materials from the regular collection. Eleven use a shorter loan period. Three stated they allow no renewals for leisure books.

Three libraries circulate leisure materials using a method other than the regular circulation system. Two libraries do not keep circulation records for leisure books. One gave no response.

Overall, most leisure collections are circulated like regular collections, although several have shorter loan periods. Again, this shows general interest in treating all library materials alike. The fewer the exceptions, the easier it is to handle circulation records.

Most respondents did not provide circulation statistics. Often these statistics are not broken out from other circulation records in automated systems. Many librarians noted there is a high interest in and heavy circulation rate of leisure materials: "High circ. collection" - Public institution of 16,000 students; "The students, faculty and staff love the browsing collection" public institution of 12,000 students with browsing collection circulation of over 9,600 .

\section{Popular Genres}

One open-ended question on the survey was "What genres appear to be most popular with your patrons?" This is, of course, quite a subjective question based on observation of what is circulated and reshelved and what is requested. The popularity of genres is also dependent on what genres are available on the shelves.

It is interesting, although not surprising, that the most popular genres identified were mystery, historical romance, fiction, science fiction, and biography. (See Table VI) Also mentioned as popular with readers were horror, adventure/thriller, spy novels, current events, sports, humor, Westerns, travel, true crime, and popular psychology.

\section{No Leisure Collection}

Of the 47 libraries stating they have no leisure collection, two were in the beginning stages of providing a book exchange at the time of the survey. The book exchange area contains materials left by students, faculty, and staff for other patrons to read in return for similar donations. "It seems to be catching on," one librarian noted on the survey.

Several respondents commented that leisure or light reading is specifically provided for and funded in the development of the collection as a whole, and is not treated as a separate collection. One of these libraries also serves as a local public library and spends $\$ 1,500$ to $\$ 2,000$ a year to purchase popular fiction and bestsellers; they also have a "light reading" magazine collection and a video collection of classic films.

In their comments, a few respondents indicated that they include fiction and other light reading as an integral part of the collection. However, two librarians commented that as academic libraries their function is to support the curriculum, not provide light reading.

Only one of these librarians made a distinctly negative comment about leisure collections: "We did away with the "leisure" collection about eight years ago ... Certainly simplified everybody's life and no one seems to miss it or expect it." This statement may refer indirectly to the fact that extra maintenance is needed to keep a separate leisure collection. No other respondents remarked on this fact, so one may assume that patrons' high interest in and use of these collections override the problems and inconvenience of providing this service.

\section{Summary and Conclusion}

This survey shows a significant interest and investment in leisure reading collections among academic libraries in the Southeast. These collections vary in composition, from paperback swap racks to rented material to popular titles rotated from the regular collection. Magazines and videos also may be part of these popular collections. Leisure materials may be bought with Friends money, a portion of the regular materials budget, or be dependent upon donations. With a few exceptions (usually paperback books), leisure materials tend to have bibliographic access and circulation control comparable to materials in the regular collection.

Academic librarians do have an interest in promoting recreational reading. Often, we expect our students will find light reading in the regular collection of books and periodicals. Providing a separate collection of popular material allows the patron to identify and access titles quickly. A separate leisure reading area spotlights and promotes extracurricular reading, which may often be overlooked in an academic environment. 


\section{Appendix A: \\ Survey of Academic Libraries' \\ Leisure Collections}

Does your library maintain a separate collection(s) for patrons' leisure or recreation?

No (If no, please skip to the last question to describe your institution)

Yes

If you do maintain such collections, please characterize them by checking all the following which apply.

Also state approximate size of the collection and fiscal year 1992/93 circulation statistics, if available.

\section{Collection of leased books}

McNaughton

Baker \& Taylor

Other (specify)

Number of titles (approx.)

Circulation, FY 1992/93

Paperback books

Number of titles (approx.)

Circulation, FY 1992/93

Magazines (separate from periodicals collection)

Number of titles

Videos

Number of titles (approx.)

Rental plan? Yes

No

Circulation, FY 1992/93

What genres appear to be the most popular with your patrons? (e.g. biography, science fiction, how-tos, mystery, etc.)

What type of bibliographic access do your patrons have to leisure materials?

Full record in public catalog

Brief record in public catalog

Separate list or card file

No bibliographic access - browsing only

Please check all the following that apply about circulation of leisure materials.

Circulation records maintained in the same system as other library materials' records

Online system Manual system

Circulation records maintained in a separate system from other library materials' records

Online system Manual system

Circulation period for leisure materials is:

Same __ Longer __ Shorter compared to similar library materials in "regular" collection.

Please describe your institution:

Public

Private

Approximate number of students

Comments or other information you would like to add:

\section{MUMFORD}

- Over 90,000 Books in Stock

- Over 10,000 Titles

- 15 Years of Service

- "Hands On" Selection

- Pre-School Through Adult
RELIABLE WHOLESALER SINCE 1977

- Discounts up to $70 \%$ Off

- Now Two Adjacent Warehouses

- Sturdy Library Bindings

- $100 \%$ Fill

- Cataloging/Processing Available

\section{MUMFORD LIBRARY BOOKS, SOUTHEAST, INC.}

7847 Bayberry Road • Jacksonville, Florida 32256 